\title{
Los arrebatos del corazón
}

\author{
Raptures of the Heart
}

\author{
FERNANDO AGUAYO HERNÁNDEZ \\ Profesor y Investigador del Instituto Mora/México \\ Plaza V Gómez Farías, 12. San Juan Mixcoac \\ 03730 Ciudad de México (DF) \\ faguayo@mora.edu.mx
}

RESUMEN En este artículo se exponen las peculiaridades historiograficas de los libros con fotografías en las que se ha abordado el devenir de la Plaza Mayor de la ciudad de México en el siglo XIX, se indica que en la mayoría de los casos se han considerado sólo las relaciones de poder que en ella se expresan. Al rescatar la plaza como un espacio en disputa en el marco de relaciones sociales conflictivas, estas líneas se plantean como una crítica al punto de vista de dicha historia oficial.

Palabras-clave praça, fotografia, México.

ABSTRACT In this article the historiographical peculiarities of the books of photographs which treat the evolution of the Plaza Mayor in Mexico City in the XIX century are revealed. It is found that in most cases only the relations of power through which the Plaza has been expressed have been considered. By recovering the Plaza as a contested space in the framework of conflicting social relations, these considerations set

Artigo recebido em 15/11/2005. Autor convidado. 
themselves up as a critique of the point of view of the so-called official history.

Key words square, photography, Mexico

Este trabajo se refiere a los usos sociales de un espacio en el que el peso que tienen las fotografías viene por partida doble. Por un lado, en la medida en que la Plaza Mayor de la ciudad de México, el llamado corazón de la capital, no tiene existencia fuera del conjunto de relaciones sociales que se han tejido a lo largo de su historia, es preciso realizar un trabajo crítico para construirlas como fuentes de primera mano para la investigación; por el otro, serán la base desde donde se busca explicar el uso que los historiadores hacen de ellas para crear una imagen histórica de este espacio tan importante en el imaginario mexicano.

El objetivo central de estas líneas es que al poner atención a un conjunto de interrelaciones humanas en una escala "micro" y sobre todo en un espacio considerado exclusivo del poder de la aristocracia porfirista, se podrá hacer a un lado esa visión simplista de una sociedad controlada por la elite, situación que luego se transformará con la revolución de 1910.Estudiar el funcionamiento real de los mecanismos del poder servirá para rescatar prácticas de los habitantes urbanos y sus mecanismos de resistencia a ese control, lo que nos llevará a poner atención a las debilidades y límites del poder, a resistir a su imagen de la vida social.

En este artículo se adopta el punto de vista según el cual las imágenes materiales y mentales que tenemos de la ciudad son un factor importante en el desarrollo de nuestras relaciones sociales. No es un trabajo que se pretenda inscribir en la historia de la fotografía, tampoco se estudió este espacio específico porque se considerara "históricamente" excepcional, sino porque al reconstruir históricamente un proceso y descifrar el papel que académicos y políticos han tenido en la interpretación de estas fotografías, surgirán algunas explicaciones acerca de la dinámica de nuestra sociedad. Vista así, la plaza mayor en el siglo XIX es un buen pretexto para intentar una explicación del uso de las imágenes en la sociedad actual.

\section{La plaza}

El espacio es producto histórico de las distintas sociedades, la imagen que nos transmite Rojas-Mix acerca del terreno virgen que después de la conquista española esperaba para la construcción de las ciudades hispanoamericanas a partir de una plaza, es una imagen limitada y ase- 
diada, en el caso de México en el siglo XVI, ${ }^{1}$ por las influencias prehispánicas que se descubren en la traza de la ciudad.

Como ya lo indicó la historiadora Sonia Lombardo, la plaza fue uno de los elementos más importantes en el lenguaje de la arquitectura prehispánica. El espacio que ocupa la actual plaza de la Constitución de la ciudad de México ya tenía esa función desde antes de la conquista española, su trazo siguió la distribución indígena y sus dimensiones estuvieron condicionadas por ella; además, al instalar su propia plaza, los conquistadores se apropiaron de la imagen del poder del estado que había tenido ese lugar durante los dos siglos de hegemonía mexica.

El núcleo central de la ciudad de México de la época colonial, denominado Plaza Mayor, fue delimitado por edificios de los principales poderes cívicos y religiosos, algunas moradas de vecinos principales, la presencia en ella del mercado, la fuente pública, la picota y la horca; estos últimos símbolos de administración de justicia. Una plaza abierta a la circulación de personas, vehículos y animales en la que se desarrollaban diversiones cotidianas que alcanzaban esplendor a la llegada de un virrey, en una parada militar o cuando se volvía una monumental plaza de toros. Desde la conquista hasta fines del siglo XVIII, aunque con modificaciones en las construcciones, se dio la convivencia de estas distintas actividades en la plaza. A partir de entonces las cosas cambian, pues el tipo de espacio que encontraremos en las fotos del siglo XIX fue producto de las modificaciones urbanas que se iniciaron en la llamada "época virreinal". 2 Se arreglan los edificios, también se pone atención a "embellecerla" con diversos implementos, pero sobre todo se dedican grandes esfuerzos a transformar los usos sociales del espacio.

Luego, después de un breve paso por una plaza llamada por unos plaza real y por otros plaza "francesa" a finales del siglo XVIII e inicios del XIX, donde acorde con el proceso de secularización en marcha lo central era la estatua del soberano, se llega hacia el tercer cuarto de ese siglo a lo que se ha denominado plaza de la independencia o plazapaseo, la cual perdura hasta 1914 (imagen 1).

La plaza-paseo corresponde a una estructura económica y a una ideología completamente diferente de la colonial novohispana. De acuerdo a

1 ROJAS-MIX, Miguel. La plaza mayor. Barcelona: Muchnik, 1978, p.112; LOMBARDO, Sonia "Construcción y uso social del espacio en la Plaza de la Constitución”. In: LOMBARDO, Sonia, et. al. Concurso nacional para la rehabilitación de la Plaza de la Constitución. México: Gobierno de la República, 1998, p.4.

2 Diversos autores de todas las épocas coinciden con este punto de vista, desde Lucas Alamán y Rivera Cambas en el siglo XIX, hasta autores contemporáneos que realizan sus comentarios a partir del análisis de dos imágenes de la época colonial. Una de estas imágenes es la de Juan Antonio Prado (atribuido). La plaza Mayor de México, pintura al óleo, de mediados del siglo XVIII y otra es de la autoría de Rafael Ximeno y Planes / Joaquín Fabregat. Vista de la gran plaza de México (LOMBARDO. Concurso nacional para la rehabilitación de la Plaza de la Constitución, p.4 y 12; MONNET, Jérome. Usos e imágenes del Centro Histórico de la Ciudad de México. México: DDF/CEMCA, 1995, p.221-223 y RIVERA, Manuel. México pintoresco, artístico y monumental. México: Imprenta de la Reforma, 1880, p.XXVII). 
Imagen 1

La Plaza Mayor de México a principios del siglo XIX

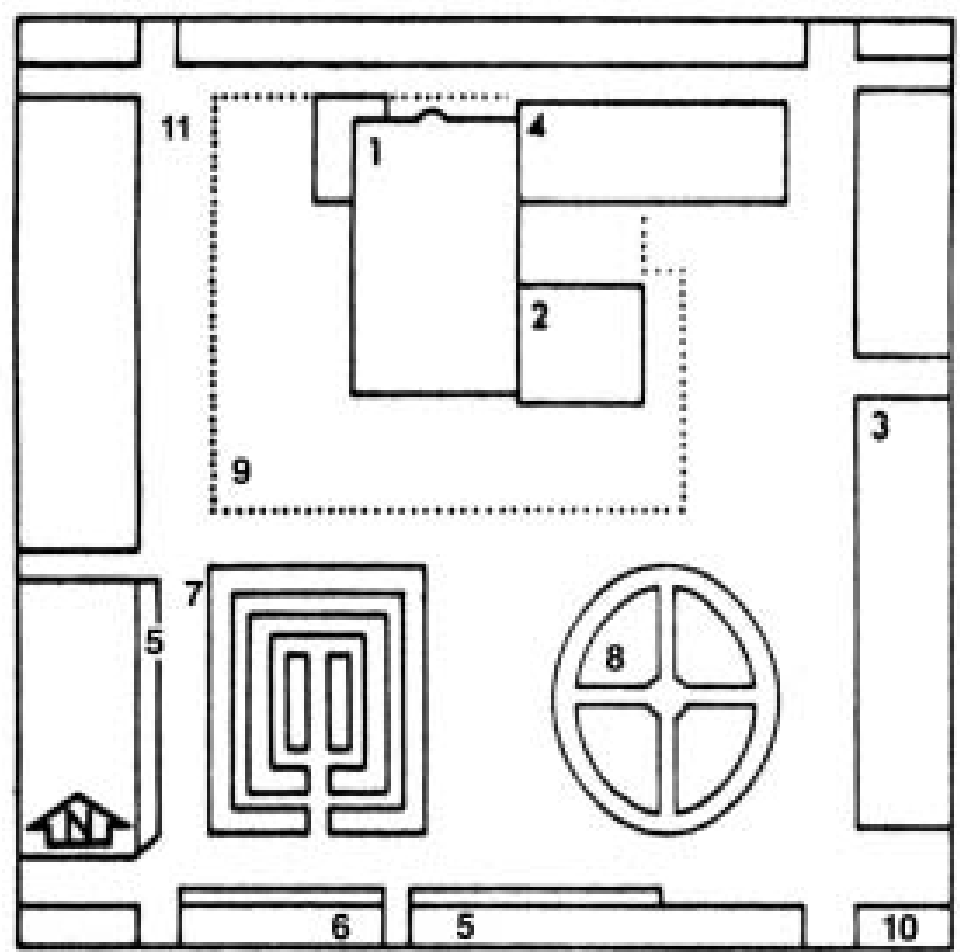

1. Catedral metropolitana

2. Sagrario metropolitano

3. Palacio Nacional

4. El Seminario conciliar

5 Portales del comercio

6. Palacio Municipal

7. Mercado del Parián

8. Estatua de Carlos IV

9. Barda atrial de la Catedral

10. Plaza del Volador

11. Capilla de los talabarteros 


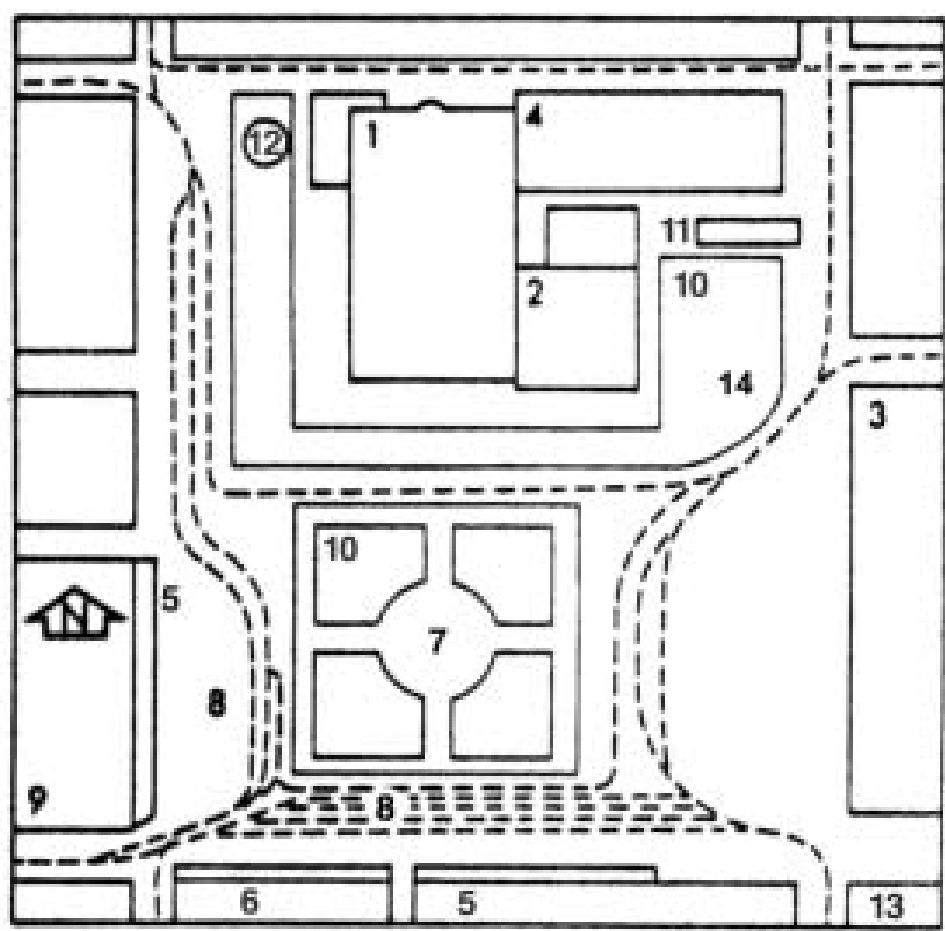

1. Catedral metropolitana

2. Sagrario metropolitano

3. Palacio Nacional

4. Edificio del Seminario conciliar, que desde el terœr cuarto del siglo XIX funcionaba comocantina y hotel

5. Portales del comercio

6. Palacio Municipal

7. Kiosco de música

8. Estaciones y líneas de tranvías

9. Establecimientos comerciales

10. Jardines públicos

11. Kiosco de libros viejos

12. Kiosco de flores

13. Mercado del Volador

14. Monumento Hipsográfico. "Posición geográfica latitud 19 16'04'5 Norte longitud 99 $06^{\prime}$ '42' '6 Oeste de Greenwich declinación magnética abril 1878 $8^{\circ} 40^{\prime} 52^{\prime \prime}$.

1. Aguayo, Fernando, La Plaza Mayor de la ciudad de México a principios del siglo XIX y XX Imagen digital construida a partir de los planos publicados en Monnet, Jérome. Usos e imágenes del Centro Histórico de la Ciudad de México. México, DDF/CEMCA, 1995, p. 269. 
los proyectos de la elite, la nueva plaza debería ser un espacio que tendría como uso principal celebrar la secularización del poder y donde se pretende que convivan sólo los sectores promotores del nuevo culto a la nación. ${ }^{3}$ Nunca será excesivo insistir en que las modificaciones, más allá de lo que pretende el discurso liberal en el sentido de que son sólo cambios en los estilos y técnicas arquitectónicas, son en realidad estrategias por medio de las cuales el poder intenta modelar el espacio urbano, en especial las plazas, de acuerdo a sus intereses y desde donde la burguesía expresa su dominio. ${ }^{4}$

Las propuestas de arquitectos y funcionarios municipales de la ciudad de México son una fuente para explicar los cambios urbanísticos y arquitectónicos, pero en este camino debemos recurrir además a las tendencias generadas en otras latitudes que se convierten en referentes para la elite decimonónica "nacional". El auge económico que experimenta México en el último cuarto del siglo XIX, es sólo una parte de la explicación. La sorprendente regularidad con la que se van transformando las plazas coloniales de las ciudades mexicanas en plazas ajardinadas, y la similitud de éstas con las plazas latinoamericanas, son una muestra de que las elites siguen a pie juntillas la propuesta de plazapaseo generada en Europa. ${ }^{5}$ Es el mundo burgués exitoso y satisfecho de sí que promueve lo que denomina la construcción de las "ciudades modernas".

Plaza Mayor, Plaza de Armas, Plaza de la Constitución o Zócalo de la ciudad de México, son todos ellos nombres que designan el espacio aquí estudiado. Hoy día son denominaciones que se usan indistintamente y sin mayores problemas. Sin embargo esto no siempre fue así, el nombre de Zócalo ocasionó conflictos entre los distintos sectores sociales, entre el "vulgo" que convivía en ese espacio y la elite liberal que implantó la plaza-paseo con una propuesta urbana específica. Escribe Ignacio Altamirano,

un congreso, uno de tantos congresos que han decretado cincuenta mil monumentos para honrar a los héroes, de los cuales monumentos no se ha hecho uno solo, había ordenado que se construyera el más grandioso en la plaza de Armas, en honor de los padres de la patria. No se hizo, por supues-

3 En otros trabajos se plantea que los proyectos buscaban que en el Paseo sólo convivieran los miembros de las clases propietarias; aquí se menciona a los sectores que estuvieran de acuerdo con ese proyecto, porque lo que molestaba e intentaba prohibir la elite no era la asistencia de los sectores populares, sino que fueran a este espacio con actitudes propias, en muchos casos, contrarias a la elite.

4 ROJAS-MIX, Miguel. La plaza mayor. Barcelona: Muchnik, 1978, p.117 y RIBERA CARBÓ, Eulalia. Herencia colonial y modernidad burguesa en un espacio urbano. México: Instituto Mora, 2002, p.10 y 294.

5 Rojas-Mix hace un recuento de los cambios que tienen las plazas hispanoamericanas que bien podría ser una descripción de la Plaza Mayor de la ciudad de México: "se ha llenado de jardines y se ha levantado el suelo como un gran pedestal embaldosado que no permite en su interior el tráfico de coches y mucho menos de carretas". La fuente ya no es abastecedora de agua, sino un puro monumento y en lugar del sitio de castigo, se "levanta un elegante kiosco de música." (ROJAS-MIX. La plaza mayor, p. 166) 
to, más que el zócalo de él. Generalmente, en materia de monumentos, en México no se hace más que el zócalo. A propósito, el vulgo [...] llama zócalos a los jardines que se establecen en las plazas principales de las poblaciones. Han acabado por creer esas buenas gentes que zócalo es lo mismo que jardín [...] Y así seguirá porque aquí tienen fortuna los barbarismos. ${ }^{6}$

A partir de entonces, en México, zócalo es sinónimo de centro, plaza principal y otras realidades que se deben investigar.

En el siglo XIX mexicano lo que se mantiene de la época virreinal es el papel de la plaza como concentradora de las instituciones del poder; incluso del religioso, menguado por las guerras de Reforma (1857-1867), irguiéndose como un espacio que centraliza la vida urbana y se pretende símbolo y fachada del conjunto de la ciudad y hasta el país, a partir del cual se ordenan las calles y la vida toda. ${ }^{7}$ Existen distintas evidencias de esta voluntad de ordenar todo a partir de la plaza mayor, unas son todo lo simbólico y cursi que se quiera, como la organización de las fiestas cívicas y la construcción de monumentos; ${ }^{8}$ otras, tienen tales efectos en la vida económica y social que no dejan de sorprendernos, como la construcción de la red ferroviaria. Diferentes estudios ya han señalado que los proyectos en este rubro llevaron a la centralización de las comunicaciones a partir de la ciudad capital: todo, ya sea hacia las fronteras o las costas, pasaba por la metrópoli. Debemos agregar a esta centralidad el hecho de que todas las estaciones ferroviarias y puntos situados en los alrededores de la ciudad de México estaban conectados por medio de los tranvías con la plaza mayor, lo que la convirtió en la estación central del sistema, cosa que, para horror o admiración de muchos, no pasó desapercibida. ${ }^{9}$

Las fotografías de la Plaza Mayor a inicios del XX dan cuenta de la red tranviaria y sus estaciones, ponen en evidencia otras modificaciones importantes de la plaza como la construcción de jardines en los que se instalan 3 kioscos y dan cuenta también de que, tras la destrucción de la alcaicería, se abre la calle 5 de mayo. En las fotografías vemos además que en el ángulo suroriente, en el espacio conocido como de los voladores, se construye el mercado del Volador en 1842 y luego otro edificio de mayor

6 ALTAMIRANO, Ignacio Manuel. Obras completas V. México: SEP, 1986, p.94-95.

7 FERNÁNDEZ, Federico. Europa y el urbanismo neoclásico en la ciudad de México. México: Instituto de Geografía UNAM/Plaza y Valdés, 2000, p.98 y ss.; y GARCíA. Antonio. Apuntes relativos a la población de la república mexicana. México: Imprenta del Gobierno, 1870, p.306.

8 Programa para celebrar el 27 aniversario de la promulgación de la Constitución. 1884 (Archivo Histórico del Distrito Federal, Volumen 1058) y Convocatoria de 1877 para la construcción del monumento llamado después hipsográfico (Archivo Histórico del Distrito Federal, Historia. Monumentos, Volumen, 2276). Recordemos también que la capital de la federación, el Distrito Federal, se definió en 1824 como una entidad circular con dos leguas de radio trazadas a partir de la Plaza Mayor (Autor no conocido. Plano estadístico del Distrito Federal. Obra mandada a ejecutar por el Exmo. Sr. Presidente de la República Mexicana. México, 1840 Mapoteca Orozco y Berra, V. 8 - 1697)

9 FIGUEROA, Doménech. Guía descriptiva de la República Mexicana. México: Ramón de S. N. Araluce, 1899, p. 252-253. 
altura, a fines del siglo XIX, que además de mercado alberga también oficinas gubernamentales; mientras que el portal de los Agustinos colonial da paso al Centro Mercantil y en el Portal de las Flores se reconstruye a la moda de la época el almacén de La Valenciana. Estos tres edificios, el Volador, el Centro Mercantil y la Valenciana son los únicos que con vocación neoclásica se construyen en este espacio, lo demás será agregar o quitar elementos en las fachadas de casi todos los edificios con este estilo y pintar de rosa el Palacio Nacional para simular un almohadillado de cantera italiana, por ejemplo. ${ }^{10}$ Vistas así las cosas, los cambios se quedaron cortos con respecto a los numerosos proyectos que se presentaron desde 1822. ${ }^{11}$ De acuerdo a planificadores y funcionarios, el problema que impidió la transformación radical de la plaza fue la falta de recursos económicos. Ya avanzado el siglo XX, cuando hubo dinero para destinarse a estos trabajos de "modernización", el estilo neoclásico había perdido su ímpetu frente a un estilo neocolonial que surgió con fuerza a fines del porfiriato y dio origen a la actual plaza "colonial", reconstruida en el siglo XX encima de los escombros de edificios coloniales y del siglo XIX.

En otros términos, la transformación más importante del proyecto de la elite decimonónica fue que se promovió el desplazamiento de la vivienda "moderna" hacia un nuevo centro localizado hacia el poniente de la ciudad. Se crea entonces un nuevo polo de desarrollo con propuestas urbanísticas específicas, que busca conectar la zona de vivienda de la elite y la de los negocios con la Plaza Mayor. Aunque éste era un proyecto esbozado también desde 1822, es decir, desde los inicios del México independiente, es hasta el tercer cuarto del siglo XIX y en un proceso que dura hasta nuestros días, que el centro comercial y financiero de la elite se va moviendo hacia el surponiente de la ciudad. Debido a este proceso es que diversos autores hablan del papel rector de los nuevos centros (por ejemplo Santa Fe) que han desplazado al que por varios siglos fue ostentado sólo por la Plaza Mayor. Hoy se pretende que el corazón de la ciudad, el Zócalo, tenga sólo un papel de añoranza y tradición, cuando no de simple atracción turística. Retomaremos este punto al cierre del artículo, pasemos ahora a las fotografías que registraron este espacio en el siglo XIX.

10 La reconstrucción "gráfica" y detallada de las transformaciones arquitectónicas de este espacio es uno de los productos de una investigación en curso. El uso de vestigios fotográficos y su transformación en fuentes para la historia se revela como una tarea de relativa facilidad en la medida que se han recopilado cerca de 500 imágenes que posibilitan trabajarlo en series por edificio, lado de la plaza, épocas, fotógrafos y otras más que permitan analizar los distintos procesos constructivos desde distintas ópticas (BURKE, Peter. Visto y no visto. El uso de la imagen como documento histórico. Barcelona: Crítica, 2001, p.20-30 y MRAZ, John. "Particularidad y nostalgia de la fotografía histórica". Nexos, México, n.91, p.39, julio, 1985. Un avance de este ejercicio se encuentra en la exposición fotográfica y catálogo AGUAYO, Fernando y Lourdes Roca. Entre portales, palacios y jardines. El Zócalo de la ciudad de México, 1840-1935. México: Instituto Mora, 2004).

11 En la Mapoteca Manuel Orozco y Berra de la ciudad de México se conservan los proyectos de Barrio Imperial de 1822, el Paseo de la Emperatriz y el del Zócalo de 1865 y los de la Exposición Nacional de 1875. 


\section{Las fotografías}

Los registros del Zócalo de la ciudad de México, tanto las copias impresas sueltas o en álbumes comercializadas por los fotógrafos, como las que fueron reproducidas en libros editados en el siglo XIX, se encuentran diseminadas por distintas partes del país y del mundo, por lo que su recuperación, lo mismo que las de otros espacios, es una tarea urgente para el patrimonio cultural. Otra tarea no menos importante en este ámbito es profundizar la investigación histórica y la documentación de los acervos gráficos para recuperar este patrimonio. En la actualidad estas piezas se encuentran casi siempre valoradas por su innegable valor estético, pero son menospreciadas en su faceta de vestigios que nos podrían ayudar a entender distintos procesos sociales, línea en la que se inscribe el presente artículo.

Las primeras fotografías de la Plaza Mayor de la ciudad de México datan del 26 de enero de 1840, ${ }^{12}$ a partir de entonces fotógrafos mexicanos y de distintas nacionalidades encuadraron este espacio con sus cámaras; gracias a ellos tenemos un registro visual de las transformaciones de este espacio. La diferencia que media entre los primeros daguerrotipos y las fotografías que encontramos a inicios del siglo XX es enorme. En 1840 los registros eran únicos, existían problemas de fijación y mantenimiento de las imágenes y los largos tiempos de exposición de hasta 15 minutos hacían imposible que cualquier objeto en movimiento pudiese registrarse. Sesenta años después las cosas cambiaron debido al conjunto de mejoras tecnológicas respecto a la capacidad de registro y procesamiento fotográfico, estas mejoras se sucedieron unas a otras con rapidez hasta lograr congelar el tiempo en intervalos más reducidos de exposición. El resultado es que paulatinamente vamos dejando de ver registros fotográficos que huían de toda escena en movimiento y buscaban sólo lo estático, para encontrar otros que capturaban el más mínimo detalle del fluir citadino, representado por el transporte y, sobre todo, por la población. Algunos autores aprovecharon estas ventajas para legarnos fotografías en las que la vida en movimiento es el objetivo, pero en la mayoría, en la medida en que el objetivo era mostrar la monumentalidad de la plaza, las personas registradas en muchas fotografías son un mero accidente que aparece en las representaciones de clásicas vistas que enaltecen a los edificios como máxima expresión de lo urbano.

Como sabemos, las fotografías son artefactos construidos por diversos actores sociales con objetivos precisos que captan, en distintos formatos y bajo ciertas limitantes técnicas, un aspecto de la vida que se

12 CASANOVA, Rosa y Oliver Debroise. Sobre la superficie bruñida de un espejo. México: Fondo de Cultura Económica, 1989, p.19 y OSORIO, Fernando. "Los daguerrotipos mexicanos en la Colección Gabriel Cromer". In: México en el tiempo, Revista de historia y conservación, México: INAH, n.22, p. 45, enero/febrero, 1998. 
desarrolla frente a ellos. Es decir, la fotografía es a la vez una técnica para producir imágenes mediante artefactos que registran la luz que reflejan los objetos y también un medio de comunicación en el que se mezclan tanto formas de pensar de quien las realiza, como expectativas con respecto a los destinatarios del trabajo. Que las imágenes más comunes del Zócalo en este periodo sean las impresionantes panorámicas arquitectónicas en las que los elementos vivos, sobre todo humanos y animales, no sean protagónicos, debe indicarnos algo de los objetivos de esa construcción.

En el periodo al que se refiere este artículo, los fotógrafos o firmas fotográficas que registraron imágenes del Zócalo son franceses como Louis Preélier, Desire Charney, Francois Aubert y A. Briquet; un solitario húngaro llamado Pal Rojti, estadounidenses como Benjamin Kilburn, Otis Gove, F. E. North, W. H. Jackson, Winfield Scott y R. J. Carmichael; además de mexicanos entre los que encontramos a Lorenzo Becerril, Cruces y Campa, Manuel Ramos y Félix Miret, y también alemanes que ya son parte de la cultura nacional como son los reconocidos Guillermo Kahlo y Hugo Brehme. En esta lista también existen editores de imágenes que les dio por darse a conocer exclusivamente como fotógrafos, entre los que tenemos al conocido C. B. Waite y a Duhart, todavía por investigarse. Cierra esta lista un gran autor que ocupa muchas de las fichas en todas las investigaciones: el no conocido. ${ }^{13}$

Plantear esta lista de autores es un atrevimiento y un compromiso en el estado actual de la historia de la fotografía. En una investigación sobre el trabajo del estadounidense Winfield Scott presentada recientemente por Beatriz Malagón, ${ }^{14}$ se reproducen dos imágenes de este autor como ejemplos de las dificultades en la asignación de autoría en la fotografía. Una de estas fotografías tiene por título Native Chile, en la que aparece impreso un copyright de C. B. Waite, la otra fotografía es Amateca Indian Matrons, la cual fue publicada recientemente con el título Tzotziles y asignándosele la autoría a un conocido fotógrafo mexicano de mediados del siglo XX, Nacho López. Estos ejemplos tienen sus peculiaridades. En un caso, un fotógrafo, editor o comerciante (o todo a la vez), contemporáneo al autor, se apropia de las imágenes; en el otro, la asignación de la autoría se debe a un error del investigador que la recopila. Ambos casos, más que situacio-

13 Uno de los problemas más significativos para trabajar con fotografías es el que se refiere a la poca importancia que se le da a la catalogación rigurosa de ellas en la mayoría de los acervos que las contienen. En una de estas instituciones, una fotografía del Zócalo de la ciudad de México, realizada por la firma Gove \& North en 1883, tiene los siguientes datos: Autor no conocido, lugar no conocido, tomada cerca de 1920. Esta situación no es culpa sólo de los archivos fotográficos, sino que se inscribe más bien en una problemática relacionada con la valoración del patrimonio histórico nacional. Para tener una visión de esta situación, ver AGUAYO, Fernando, et. al. Revelando el rollo. México: Instituto Mora, 2002 y AGUAYO, Fernando y Lourdes ROCA. Imágenes e investigación social. México: Instituto Mora, 2005.

14 MALAGÓN, Beatriz. La fotografía de Winfield Scott. Entre la producción comercial y la calidad estética de la fotografía. Tesis de doctorado en Historia del arte. México: Facultad de Filosofía y Letras, 2003. 
nes anómalas en el tema de la fotografía son comunes en el medio académico mexicano, debido a la poca investigación histórica en este campo.

Ante las numerosas imágenes de Scott atribuidas a C. B. Waite, Beatriz llega a la conclusión de que Waite, más que un fotógrafo, fue un empresario con trabajadores de la lente a su servicio, una firma bajo la cual se pierden la autoría de otros fotógrafos. Beatriz señala que el objetivo de Waite era crear una agencia fotográfica, pues este personaje tenía la infraestructura para editar el material fotográfico por su cuenta. Por eso su tendencia a controlar los registros de otros autores, lo cual, además, le hacía obtener ingresos extra. La conclusión a la que llega Beatriz Malagón es totalmente acertada y puede servir para ampliar la investigación sobre la fotografía. En esta investigación sobre las imágenes del Zócalo encontré una fotografía en el archivo de la Propiedad Artística y Literaria del Archivo General de la Nación registrada con la autoría de C. B. Waite (imagen 2), sin embargo esta imagen fue publicada en 1903 en un libro en el que se agradece la colaboración de R. J. Carmichael, autor de las fotos. ${ }^{15}$

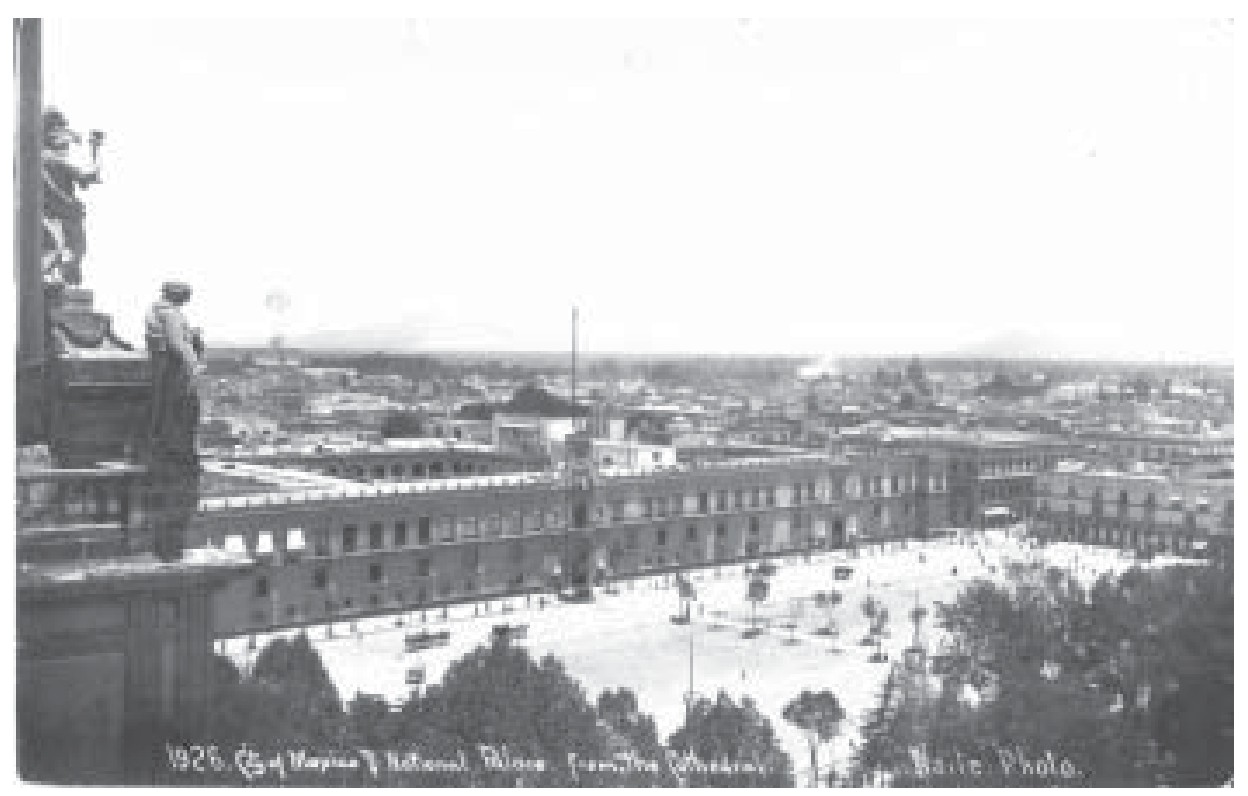

2. R. J. Carmichael (fot.) y C. B. Waite (edit.), 1926. City of Mexico and National Palace from the Catedral, ca. 1900. Archivo General de la Nación, C. B. Waite, ciudad de México 13.

15 SOUTHWORTH, J. R. México Ilustrado, Distrito Federal. England: Blake \& Mackenzie, 1903, p.9. Es preciso insistir que el caso de Waite no es único, ni los mecanismos y chapucerías para hacer desaparecer nombres y autorías de las fotos se remiten a los que él empleó (borrar el nombre en los negativos y colocar títulos en las imágenes, recortar las piezas donde existían los datos, etc.). Por ejemplo, ante el caso de las imágenes de A. Briquet del Ferrocarril Mexicano realizadas entre 1872 y 1874, en las que la firma del fotógrafo aparece en los ángulos inferiores, qué solución más espléndida que la empleada por el editor Julio Michaud al colocar una mascarilla ovalada que resolvió satisfactoriamente el problema. Ver: AGUAYO, Fernando. Estampas ferrocarrileras. México: Instituto Mora, 2003. 
Beatriz Malagón señala que esta situación se debe en parte a que los fotógrafos no eran muy dados a registrar su obra, cosa que sí hacían los editores. Eso explica, que, como apunta esta autora, se hayan publicado fotografías con la firma clara de Scott en libros de Waite editor sin que mediara ninguna explicación, lo mismo que fotos de Briquet y otros autores a los que no se les reconoce la autoría, lo cual, hasta donde se sabe, no generó pugnas legales.

Un camino que puede ayudar en el asunto de la autoría es definir una forma distinta de construir la "paternidad" de las obras, como ya se ha hecho con el prolífico William Henry Jackson. En este caso existen evidencias de tomas realizadas casi en el mismo instante con formatos que van desde las estereoscopias a formatos de tamaño $5 \times 7,8 \times 10$ y hasta $20 \times 24$ pulgadas, lo cual sólo era posible porque Jackson estaba al mando de una legión de hasta quince personas que incluía operadores de cámara, limpiadores, asistentes, impresores, montadores, retocadores, coloristas y hasta cargadores y otros peones que son utilizados como escala humana en determinadas tomas. No ha existido quien señale como falsa la "autoría" de Jackson, más bien se ha contextualizado su producción para entenderla como la de un director que no dejó fuera el asunto de los derechos autorales y patrimoniales ni la comercialización de las piezas.

Una primera tarea para avanzar en este sentido ha sido sistematizar el conjunto de imágenes con criterios tomados del análisis documental y otra pendiente será descifrar las distintas prácticas profesionales de los fotógrafos para trascender la imagen del artista inspirado y su preocupación estética, que desde luego existía, y así poder construir una explicación más compleja que incluya en estas variables la de investigar las firmas fotográficas para descubrir sus relaciones de trabajo, las visiones del mundo del fotógrafo y de sus promotores, comitentes, patrones; así como el estado del mercado visual en la época y un insospechado etcétera en curso.

Louis Preélier realizó los primeros registros fotográficos del Zócalo y la ciudad de México en 1840, Desire Charney lo hizo alrededor del año 1858, lo mismo que el húngaro Pal Rojti, mientras que la época del Imperio (1863-1867) fue también el momento del famoso François Aubert. A. Briquet realizó sus registros del Zócalo en diversas fechas, primero entre 1872 y 1874, coincidiendo en esa época con Benjamin Kilburn, luego alrededor de 1883 y después al finalizar el siglo XIX. De Lorenzo Becerril y de la firma Cruces y Campa tenemos fotografías del Zócalo en 1880. La sociedad Gove \& North nos legó fotos que podemos fechar entre 1883 y 1885, mientras que W. H. Jackson lo hace entre 1882 y 1883. Los estadounidenses Cox, J. R. Carmichael, Winfield Scott y C. B. Waite hacen registros en el cambio de siglo; por su parte Guillermo Kahlo y Félix Miret, desde el cambio de siglo hasta el final del porfiriato. 
En el caso de la firma Cruces y Campa, considerados fotógrafos de estudio, encontramos que bajo el rubro "personajes" tienen un par de fotografías del Zócalo realizadas en 1880, tres años después de desaparecida su asociación. ${ }^{16}$ De otro "retratista", el poblano Lorenzo Becerril, hemos localizado sólo unas cuantas imágenes y la sospecha de que tuvo un grado de colaboración o relación con el trabajo de la firma Gove \& North. Por otro lado, como ya se indicó, de la abundante producción que Waite registró con su sello, apenas se empiezan a desgajar autores y piezas, tarea que llevará un buen tiempo para concretarse. Acerca de Duhart y Félix Miret, son sólo dos nombres que aparecen en registros de fotografías en el Archivo General de la Nación; se sabe que Eduardo Melhado es uno de los fotógrafos de la firma Miret, mientras que algunas de las publicadas por Duhart son de Kahlo, pero no sabemos más.

En cambio, de Guillermo Kahlo se han hecho exposiciones a nivel nacional y publicado varios libros acerca de su obra. Esta sistematización de su trabajo, al igual que la investigación de Winfield Scott, presenta una buena base para localizar algunas de sus imágenes y observar la forma en que se publicaron. En cuanto a muchos de los autores "no conocidos", las piezas que hemos encontrado publicadas están ligadas a instituciones gubernamentales, por lo que la búsqueda en los archivos oficiales (el Ayuntamiento de la ciudad de México, la Dirección de Obras Públicas, etc.) ofrecerá más adelante algunas respuestas.

\section{Las fotografías, su publicación y la imagen de la ciudad}

Si ya la asignación de autorías es un asunto complicado, otro es responder a la pregunta ¿por qué se publicaron y se siguen publicando sólo determinado tipo de fotografías, si existen cientos de imágenes de este espacio? En estas líneas se avanzará con un solo ejemplo, las hipótesis que se extraigan de él serán provisionales y podrán matizarse o revisarse al profundizar la investigación y llegar a conclusiones más sólidas. Como lo han señalado varios autores, en esta época encontramos una abundante producción de publicaciones realizadas en el país y en el extranjero, en español, ediciones bilingües o en distintos idiomas, en las que los géneros "iban desde la crónica de viaje a estudios geográficos, agrícolas y mineros, así como compendios históricos que hacían culminar en el porfirianto el ciclo evolutivo de la nación". ${ }^{17}$ Hasta este

16 Una investigación sobre la sociedad de Luis Campa y Antíoco Cruces indica que ésta inició en 1866 y dejó de funcionar en 1877 (MASSÉ, Patricia. Cruces y Campa. México: CONACULTA/Círculo de arte, 2000, p.12), Antíoco Cruces mantuvo el establecimiento fotográfico situado a un costado de catedral, puede ser él quien realizara las fotos mencionadas o que lazos previos a las noticias del fin de la "razón social Cruces y Campa", pudieran generar esa referencia al trabajo común en 1880

17 RIGUZZI, Paolo. "México próspero: las dimensiones de la imagen nacional en el porfiriato". Historias, México: Dirección de Estudios Históricos del INAH, v.20, p.142, abril-septiembre 1988. 
momento la fotografía que más se ha encontrado reproducida en eso libros es la que aparece con la marca "Go Kahlo, foto. № 5". Publicada en el álbum Mexiko de 1904 aparece una leyenda que indica "Plaza principal (Zócalo), lado del Oriente: Palacio Nacional, N.O. al S.E". Se trata de una fotografía tomada desde una torre de la catedral, el fotógrafo encuadró el Palacio Nacional, detrás de este edificio se adivina la ciudad y al frente sólo existe un espacio casi vacío. Los árboles en primer plano y las diminutas figuras humanas son totalmente prescindibles, no así el vehículo jalado por dos caballos que llama poderosamente la atención. Si en el conjunto de acervos y publicaciones hiciéramos un recuento de las imágenes fotográficas que existen con este encuadre, fácilmente llegaríamos a la conclusión que ésta es la imagen de la plaza que con mayor frecuencia se registró.

Llegar a ella tuvo varios tropiezos. Desde los inicios de la fotografía en nuestro país y durante treinta años los temas más recurrentes de las imágenes que se hacían de la Plaza Mayor eran la catedral y/o el sagrario, en cambio, en estos treinta años son pocas las fotos que encuadran el palacio nacional. Posteriormente, la construcción del Paseo y los árboles frente a la catedral fueron un obstáculo para que las fotografías lograran esas composiciones de la catedral, entonces surge esta reiterada imagen del Palacio realizada desde diversos ángulos. Es interesante que entre las fotografías registradas en el acervo de la Propiedad Artística y Literaria por C. B. Waite existen varias imágenes (entre ella la imagen 2 aquí publicada) que fueron tomadas con ese mismo tiro de la cámara desde diferentes emplazamientos en la parte superior de catedral ¿Es esta la imagen de la Plaza Mayor de la ciudad de México? No es muy aventurado decir que para muchos la respuesta es afirmativa, o en todo caso esta es una imagen más aceptable que otras.

Hasta donde se ha investigado, las fotografías estilo "vistas", realizadas por fotógrafos profesionales desde la parte superior de los edificios y dirigidas hacia distintos puntos de la plaza, especialmente al Palacio y la Catedral, y que tienen como característica distintiva el hecho de que no aparecen personas en la plaza o no se les pone atención en el momento de realizar las tomas, son el tipo de imágenes que más se conservan en archivos públicos y colecciones privadas y, lo que es más interesante, las que más se imprimieron en los libros de época y más se reproducen actualmente por los académicos en las publicaciones con temas históricos. Es importante señalar que estas imágenes, en particular la de Kahlo mencionada, fueron insertadas en algunos libros para ilustrar el apartado "ciudad de México", asumiendo la propuesta de que "la plaza es la fachada de la ciudad", por no decir su imagen. 


\section{Las imágenes con movimiento}

Existen fotografías distintas a las "vistas" reseñadas anteriormente, pero casi no fueron reproducidas en su momento ni son incorporadas por los académicos en la actualidad. Algunas de estas piezas son las que generaron principalmente algunas instituciones gubernamentales, el municipio de la ciudad de México y las distintas secretarías de estado. Este tipo de imagen es lo más parecido a un trabajo documental, en el sentido de que fueron fotos realizadas de manera específica para informar acerca de un hecho preciso y no mostrar "la plaza" o "la ciudad" en general. Este tipo de fotografías tiene sus peculiaridades y nos sirve sobre todo para hacer una reconstrucción de diversos procesos arquitectónicos y de modificaciones de la plaza. Un ejemplo de este tipo de imágenes es la que viene incluida en la Memoria de los trabajos del Ayuntamiento de la Ciudad de México para el año 1895. En esta obra se publicó una fotografía para mostrar el deterioro del Portal de los Agustinos producto de los sismos de ese año, la imagen y el texto que la acompaña buscaba justificar la destrucción del dañado edificio del siglo XVIII.

Es importante señalar que también en muchas de las fotografías tipo "vista", creadas por los artistas como Cruces y Campa, Briquet, Jackson y Becerril, existe información acerca de estos procesos materiales, sin embargo, en estas imágenes, la información que rescatamos fue captada sin ser un objetivo del "artista", es decir fue registrada de manera circunstancial. En 1897 la esquina del portal de Agustinos vuelve aparecer en una foto de A. Briquet; el francés la tituló No. 155 Vista Panorámica, México. En esta imagen aparece claramente el proceso de construcción del edificio que sustituyó al viejo portal, de hecho este registro "involuntario" es uno de las pocos que se conocen de este proceso, sin embargo esta pieza se comercializó como una "vista", lo cual condicionó su lectura y el uso mayoritario de esta fotografía como imagen de la ciudad.

Se ha dicho que las fotografías captan un instante de la vida que se ha detenido frente a las cámaras, "congelan las circunstancias sociales más dinámicas e invisibles y las presentan como rebanadas delgadas e inmóviles que son perfectas para el estudio de distintas sociedades históricas". Sin embargo, su remisión a "imágenes de época", en postales o libros conduce a un acartonamiento de la vida. Nuestro trabajo es buscar diversos mecanismos para lograr el movimiento en las escenas. Este proceso se debe realizar recurriendo a distintos mecanismos, de acuerdo al tipo de fotografías y formas de publicación. ${ }^{18}$

18 MRAZ, John. "Particularidad y nostalgia de la fotografía histórica". Nexos, México: Nexos, n.91, p.38-42, julio 1985 
En el caso de las piezas que hemos denominado de estilo documental es posible recobrar información de diversos fenómenos urbanos, tienen fecha y contexto de producción; sin embargo esto no basta, la investigación histórica debe dar cuenta de otros elementos explicativos. Siguiendo el caso del Portal de Agustinos, en 1895 - 96 el Ayuntamiento decidió otorgar el permiso a su propietario para destruirlo y construir en su lugar el edificio más moderno de la ciudad de México de entonces, el Centro Mercantil. En caso de que quisiéramos investigar qué idea acerca del valor del patrimonio arquitectónico existía entre los miembros del Ayuntamiento en esa época, lo más seguro es que no encontráramos ninguna referencia al periodo colonial, sino el valor del "moderno" patrimonio que se construía con estilo neoclásico.

En nuestros días, Guillermo Tovar y de Teresa, en su famosísimo libro La ciudad de los palacios: crónica de un patrimonio perdido, se lamenta de la destrucción del venerable edificio colonial que era el portal de Agustinos y explica el proceso señalando el odio que tenían hacia ese tipo de arquitectura los "ilustres liberales". Por su parte, Enrique Krauze, encargado de prologar ese libro, comparte esta visión sobre la historia en la que no existen explicaciones y en la que, por regla, debemos mostrar una inocente perplejidad: "Nunca entenderemos cabalmente por qué hombres sin tacha cívica y moral como los liberales de la Reforma fueron ciegos a la grandeza del pasado colonial e implacables en su voluntad de negarlo y suprimirlo".

Tovar y de Teresa nos dice que su libro "constituye una muestra considerable de cuanto podría mostrarse acerca de los monumentos desaparecidos de la antigua ciudad de México y sus alrededores". Además de precisar el papel del material gráfico que incluye en su trabajo: la preferencia por ese tipo de material, leemos en una de sus páginas,

se explica entre otras cosas porque los testimonios ofrecidos son irrefutables a través de documentos tales como fotografías realizadas desde su introducción a México a mediados del XIX [...] amén de los testimonios escritos que los describen... ${ }^{19}$

Sin embargo, como se puede leer en los documentos oficiales de la época, el asunto del deterioro del edificio, su destrucción (previa indemnización al propietario) y posterior instalación de un edificio estilo neoclásico, se desarrolló con todas las bendiciones del Ayuntamiento de la ciudad de México al propietario del inmueble y también funcionario municipal, el señor de Teresa, después propietario del flamante Centro Mer-

19 TOVAR y de TERESA, Guillermo. La ciudad de los palacios: crónica de un patrimonio perdido. México: Vuelta, 1994, p.XIX-XXI. 
cantil. Trabajos de investigación, en los que por cierto la imagen no cuenta casi para nada, han desarrollado explicaciones acerca de que los procesos de conformación de las elites liberales en el poder se consolidaron sobre la base de crear intereses económicos con grupos que acrecentaron su poder económico a costa de las propiedades de la Iglesia; es decir, a costa de todos esos edificios y predios de la época colonial que estudia Tovar y de Teresa. Estos predios, según consta en documentos de archivo, fueron vendidos a particulares como los Escandón, los Landa, los Tovar, los Teresa y otros apellidos nobles que acrecentaron su riqueza explotando sus propiedades urbanas, proceso que fue plasmado por Constantino Escalante en una implacable caricatura que tituló Adivina adivinador, cuál de estas aves vuela mejor. En ella, políticos liberales y empresarios vuelan como aves de rapiña saliendo de Palacio Nacional sosteniendo entre sus garras las fincas obtenidas en remate. Por eso el contexto de estas fotografías no es el "patrimonio perdido", sino los negocios especulativos que dejaron una gran fortuna a la elite, al modelar la ciudad desde el municipio, comprando edificios expropiados a la Iglesia a precios irrisorios, destruir las construcciones coloniales y reconstruir a lo moderno en su lugar. ${ }^{20}$

Como hemos visto, también las fotografías estilo "vistas urbanas" son factibles de utilizar en la reconstrucción de las transformaciones en el espacio urbano y en tejer explicaciones que orientaron estos procesos. La tarea no es nada fácil porque, por ejemplo, cuando uno de los más connotados especialistas de la historia de la fotografía en México publicó lo que se puede considerar como el primer daguerrotipo de la ciudad capital, utilizó sólo información proveniente de documentos escritos para fecharla entre 1839 y 1843; los elementos de la propia imagen fueron secundarios y nunca definitorios para que éstos indicaran la fecha de realización de la toma. Por eso, antes de caer en la tentación de leer todo en la imagen, debemos profundizar en metodologías para analizar éstas en un diálogo continuo con otras fuentes de archivo.

En la búsqueda de diversos vestigios del siglo XIX mexicano fue fácil toparse con varios de los novelistas y narradores de la época que reseñaban diversos aspectos de la vida en la plaza, usarlos sólo de manera referencial es limitado frente al hecho de que existe una sorprendente sincronía entre las imágenes que generan los artistas gráficos y los literatos. Por ejemplo, para el caso del portal de Agustinos, Ángel de Campo señala que derrumbar el portal y construir un edificio moderno se justifi-

20 La historia de los negocios que siguieron a los procesos de desamortización está pendiente; buena parte de la información que servirá para tal efecto se encuentra en los documentos de archivo. Por ejemplo, para el caso que nos ocupa en el Archivo de la Propiedad Inmueble Federal, exp. 65/25691; AYUNTAMIENTO. Memoria. México: Imprenta de Francisco Díaz de León, 1896, p.42, 58-59 y 176-177; para la nota gráfica y nostálgica, ver: TOVAR, La ciudad de los palacios, p.16 y 114-115. 
caba plenamente puesto que ese espacio del Zócalo era el rostro de la calle, la primera impresión de la urbe.

La imagen de la ciudad, la primera impresión de la urbe, el asunto va más allá de una simple coincidencia. La Imagen se forma dentro de un sistema de referencias y de valores comunes a un grupo; Ángel de Campo es parte de las elites, sin embargo es un escritor especial. Ángel de Campo ha sido calificado como "portavoz de los pobres", "poeta de los humildes", "voz del genuino sentimiento del pueblo que comprende a las clases pobres"; escritor realista que recreó las costumbres de su tiempo "cercano a las clases miserables". Unos incluso lo califican como subversivo y adversario del machismo, otros lo señalan como crítico social que toma la causa de los desheredados como reflejo de la época prerrevolucionaria en la que vivía. Lo más interesante es que en todos los tiempos lo han señalado como creador de imágenes, psicólogo, pintor acucioso, pintor de la vida moderna. Uno de sus biógrafos escribió: su dibujo es asombroso, su color brillante y enérgico, su mirada de curioso es microscópica. Y, el colmo, Luis G. Urbina lo describe así: "Ángel de Campo poseía un facultad retentiva verdaderamente estupenda. Lo que él veía quedaba para siempre grabado en su cerebro como en una placa fotográfica". ${ }^{21}$

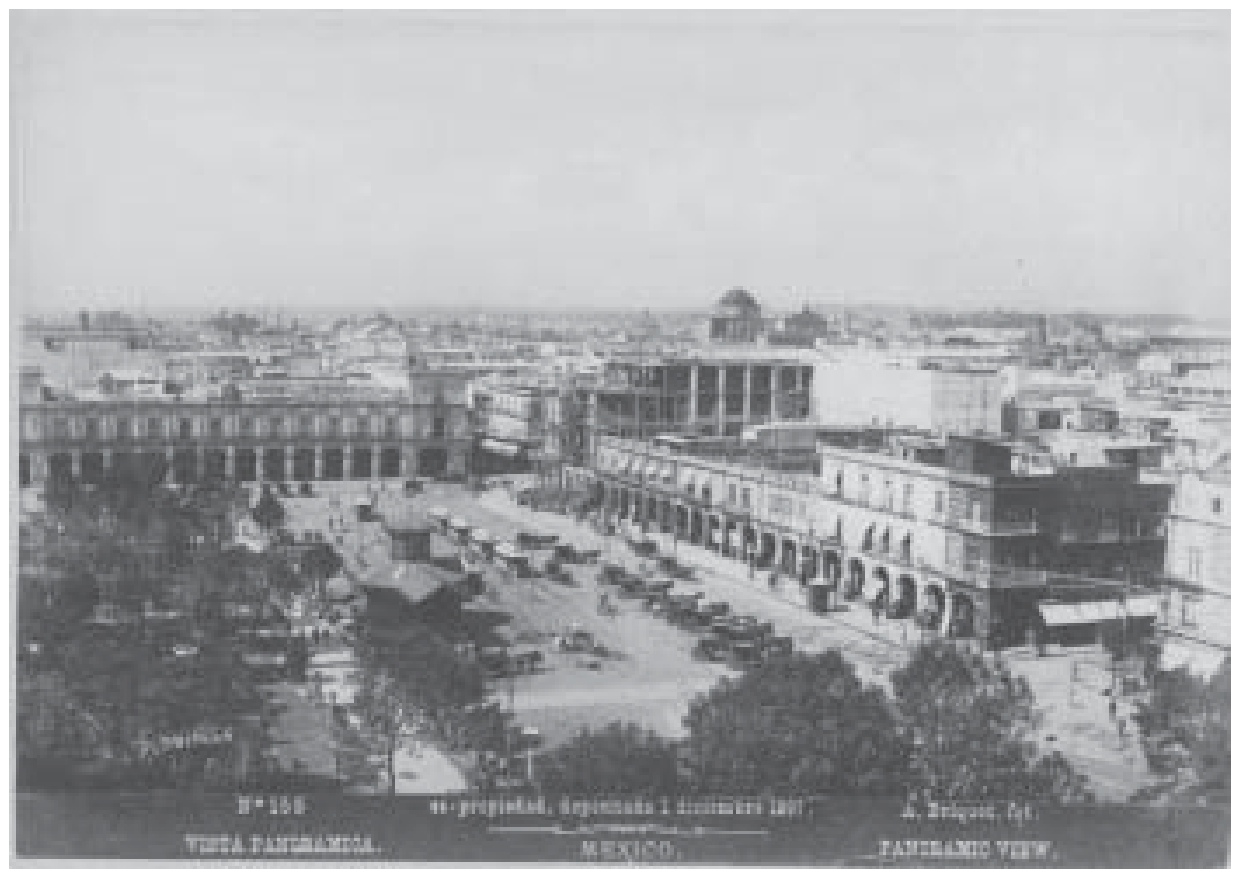

3. A. Briquet, No. 155 Vista Panorámica, México, 1897. Universidad Iberoamericana. Biblioteca Francisco Xavier Clavijero, Colección Biblioteca Manuel Arango Arias.

21 GONZÁLEZ, Alejandra. La ciudad palpitante. Tesis de licenciatura en Historia, México: UNAM/Facultad de Filosofía y Letras. Colegio de Historia, 2004. 
Ángel de Campo es miembro destacado de la elite porfirista que actúa en la cruzada para trasformar la sociedad. El proyecto liberal, en el que juegan un importante papel las imágenes, busca construir ciudadanos, personas que rechacen el sistema de valores de la sociedad tradicional. Se trata de "una verdadera transculturación" de esos pobres acerca de los que escribe Ángel de Campo. En este proceso, los artistas e intelectuales, fotógrafos y literatos, "están sometidos a los arquetipos del discurso dominante, y son a la vez sus mejores productores y propagadores sin ser necesariamente conscientes de la coherencia y de la eficacia de sus actos y sus palabras". ${ }^{22}$

Cuando Ángel de Campo escribe acerca de los pobres, existen testimonios de ello, produce en sus lectores de ayer y hoy un gran regocijo debido a las minuciosas pinturas de la vida urbana. Sin embargo, después del disfrute, viene el sentimiento de pesar, puesto que en "la ciudad privilegiada, dispuesta como un aparador", se presentan esos comportamientos de los pobres ante los cuales los promotores de lo moderno deben sentir vergüenza. Utilizar el trabajo literario de Ángel de Campo, más allá de la información referencial que aporta, implica realizar un trabajo sistemático para contextualizar su práctica social; sin embargo, la ganancia que se puede obtener es introducir una rica narración que ayude a dar cuerpo y movimiento a los vestigios de los sectores que resistieron el proyecto modernista y ciudadano; descubrir, con la ayuda de otras fuentes, que bajo el discurso paternalista con que describe a "Ios pobres", se encuentra el registro de las acciones de estos sujetos en un espacio importante que disputó con tenacidad a las elites: el Zócalo de la ciudad de México, el corazón de la ciudad.

\section{El espacio y la historia en disputa}

La principal manifestación social que ha generado vestigios gráficos a lo largo de la historia del Zócalo ha sido la del poder. En algunos periodos incluso ha sido la única práctica política permitida; personas o instituciones podían hacer uso de la plaza para exponer sus puntos de vista siempre y cuando se pronunciaran de acuerdo con lo que dijeran los representantes del poder en turno. Por esta razón, desde los inicios de la fotografía en nuestra ciudad, el tipo de imágenes del Zócalo que sobreviven con este tema son aquellas que registran actividades que distintos regímenes realizaron para celebrar las fechas que previamente decidían que eran importantes para legitimarse.

22 MONNET, Jérome. Usos e imágenes del Centro Histórico de la Ciudad de México. México: DDF/CEMCA, 1995, p.22 y 325. 
Una de estas fotografías del Zócalo fue publicada en 1902 con la siguiente leyenda:

Los reservistas de la capital desfilan frente al señor Presidente de la República el día de su cumpleaños (15 de Septiembre 1902)». Se trata de la conocidísima imagen que ha sobrevivido desde la noche de los tiempos en cualquier plaza del planeta. Los poderosos observan desde su palacio la marcha militar que los alaba. Sin embargo, páginas adelante, la misma publicación incluyó una fotografía en la que el Zócalo se encuentra llena de gente en un ambiente de fiesta popular. En esta otra imagen nadie tiene la atención puesta en el Palacio Nacional, sino en la convivencia con sus iguales, sin embargo el poder llama al orden y nos dice que esa fotografía se debe entender como el momento en que «Los reservistas rompiendo filas, y enarbolando banderines rojos, hacen una demostración de simpatía al señor Presidente de la República el día de su cumpleaños (15 de Septiembre 1902). ${ }^{23}$

Hoy día la mayoría de los académicos que trabajan con fotografías de la ciudad de México en el periodo del cambio del siglo XIX al XX tienen críticas a la "política social" del régimen porfirista, acotamientos que no son nada frente a la fascinación que les producen las imágenes de la ciudad en el porfiriato. En esos artículos o libros aparecen multitud de fotos y páginas en las que se describe la calidad de las imágenes y los logros materiales del régimen, amplias referencias al "orden y progreso", salpicados con pequeños señalamientos de que ese régimen dio origen a la dictadura porfirista o, más impactante, la definición de ese gobierno como la "noche porfiriana", la cual sólo acabará con el estallido revolucionario. Diversos historiadores aceptan, por ejemplo, que la llamada "noche del grito" del 15 de septiembre en la que se recordaba el inicio de la independencia, fue transformada exitosamente en la celebración del cumpleaños de Porfirio Díaz.

Sin embargo, como es fácil concluir, la mayoría de las fotografías del Zócalo que se conservan de la época reflejan en gran medida la propuesta "social" y urbana de la elite porfiriana a la vez que la promueven. No se trata de una época dorada de progreso material en la que las propuestas urbanas y las festividades tenían objetivos comunes para toda la población, bella época que termino por culpa de un dictador; ${ }^{24}$ sino de

23 REYES, Bernardo. El general Porfírio Diaz: estudio biográfico con fundameteos de dados auténticos y de las memorias del gran militar y estadista, de las que se reproducen los principales paisajes. México: Editora Nacional, 1960.

24 En estos trabajos se recuerda un tiempo en el que las festividades tenían popularidad, la cual se puede constatar con fotografías, "antes de que se convirtieran en refrendo del inamovible poder de Díaz". A partir de entonces, las imágenes sólo "documentan la organización del aparato de Estado." (CASANOVA, Rosa. "Las fotografías se vuelven historia: algunos usos entre 1865 y 1910". In: RAMÍREZ, Fausto, et. al. Los pinceles de la historia. La fabricación del estado 1864-1910. México: Museo Nacional de Arte/BANAMEX/UNAM/Instituto de Investigaciones Estéticas/ CONACULTA-INBA, 2003, p.234 y ANCIRA, Eduardo "Fotógrafos de la luz aprisionada". In: AGUAYO, Fernando y Lourdes Roca. Imágenes e investigación social. México: Instituto Mora, 2005, p.334-353). 
procesos sociales conflictivos en los que las elites buscaron imponer sus propuestas, contra las que siempre hubo resistencia de distintos sectores.

Para nadie es extraño que la elite construya una historia a su medida, que seleccione de entre todos los vestigios del pasado, incluidos los fotográficos, los que fueron generados con el punto de vista de los propietarios; otra cosa es que permitamos que además se nos imponga la manera en que estos vestigios se deban leer. En otros productos de esta investigación sobre las fotografías del Zócalo de la ciudad de México ya se demostró que incluso las fiestas cívicas eran momentos en los que posturas encontradas de cómo y qué celebrar se hacían presentes. Existen evidencias documentales de que después del desfile militar los sectores populares se apropiaban del Zócalo con consignas que apelaban a su libertad e independencia frente al poder. ${ }^{25}$

Un estudio más amplio realizado en fuentes escritas indica que esta situación es constante a lo largo del siglo XIX. Tratándose de las celebraciones del culto católico o las de la patria, pues en todo momento encontramos bandos apelando a "la docilidad e ilustración del pueblo mexicano" para que en paseos y calles tenga un comportamiento de "circunspección y reposo". De no ser así, reglamentos y toda suerte de prescripciones se harán valer para evitar "desórdenes" que empañen las conmemoraciones. ${ }^{26}$ En esa sociedad en la que existían brutales desigualdades sociales y económicas, se pretendía que los distintos sectores acudieran a la plaza a celebrar el poder sin chistar. La situación no ha cambiado mucho. El México actual es definido por el historiador Eric Hobsbawm como el campeón de la desigualdad. La acumulación de la riqueza social en manos de las elites se acentúa y la celebración de las "fechas de la nación" en la Plaza Mayor por parte del poder sólo es posible convirtiéndola en un espacio en estado de sitio. Por el contrario, en muchas ocasiones, sólo es necesaria una causa que reclame el consenso de la población para que el Zócalo, el corazón de la patria, se vea inundado de personas que obligarán al poder a echar marcha atrás en sus propuestas.

Ayer (y hoy) el poder afirma que cualquier reunión de más de dos "ciudadanos" en la plaza pública es una manifestación para alabar su carisma y popularidad. Registra las imágenes de las multitudes que se reúnen en esos sitios y las publica como prueba contundente de su aceptación. Contrarias a esa visión, existen investigaciones sobre la ciudad

25 AGUAYO, Fernando y Lourdes Roca, Entre portales, palacios y jardines, p.60-70.

26 Las frases provienen del bando publicado con motivo de La celebración de la Independencia, fechado el 14 de septiembre de 1825, citado por GORTARI, Hira y Regina Hernández. Memoria y encuentros: la ciudad de México y el Distrito Federal (1824-1928). t.III. México: DDF/Instituto Mora, 1988, p.486. En esta obra se reproducen una serie de documentos que a lo largo de un siglo nos muestran estas prescripciones. 
de México que, abrevando de los fondos judiciales y de policía, han rescatado a la multitud con sus consignas. En cambio, las imágenes de ayer, realizadas por artistas de una calidad indiscutible, son alabadas por muchos historiadores de hoy sin discutir la imagen que el poder se construye con su ayuda. Con estas posturas se asume una imposibilidad social frente a las medidas dictadas por el poder, lo que no pasa a ser más que su apología. Sin embargo, como todos sabemos, ayer y hoy, la resistencia más exitosa a esta imagen no se ha dado por la vía de la creación de otras imágenes alternativas, sino en la práctica, en el uso y disfrute del espacio.

El Zócalo de la ciudad de México, esta plaza pública que reniega del centralismo del poder que se le quiere imponer, sigue siendo para muchos el disputado corazón de una propuesta por construir una vida mejor en la que las desigualdades sociales no se alaben como logros del progreso. Es seguro que en esa propuesta el papel de la crítica historiográfica y la crítica a las imágenes del poder tiene un papel nada despreciable; en estos arrebatos del corazón es tiempo de asumir nuestra tarea. 